\title{
IIIIII 創莧研究の新潮流38
}

創 薬

シリーズ(8)

\section{生活習慣病を標的とした治療ワクチンの開発}

\section{中神 啓德}

要約：ワクチンは 18 世紀にジェンナーが牛痘にかか ると天然痘にかからないという言い伝えから牛痘によ る天然痘ワクチンを思い立ったと言われている。近年 この技術は様々な疾患へと応用され，アルツハイマー 病のアミロイド $\beta$ やタウを標的としたワクチン治療の 基礎研究・臨床試験なども行われている. 我々も高血 圧などの生活習慣病に対するワクチンの開発研究を進 めており，毎日の内服薬から年に数回のワクチンによ る治療の実現を目指している。これらの内因性夕ンパ ク質を標的としたワクチンでは体液性免疫を活性化し て抗体産生を促すことが主目的となるため，抗原， キャリア，アジュバントの適切な選択が求められる. 臨床的メリットとしては薬物アドヒアランスの改善が 挙げられ，特に高齢者における薬の多剤併用（ポリ ファーマシー）の増加により, 飲み忘れや服薬管理の 必要性が高い患者が増加しており, 薬郕を減らすこと による社会的なメリットは大きいと考えられる。

\section{1.はじめに}

ワクチンは感染症に対する予防治療としてその歴史 は長く, 集団社会での感染症の流行を防ぐ「集団免疫」 の観点で医療に多大なる貢献をもたらしてきた。この 医療技術を応用してがん治療やアルツハイマー病など の慢性疾患治療に応用する基礎研究および臨床試験が 始まっている。我々が取り組んでいる生活習慣病を標 的としたワクチン開発研究も, 高血圧ワクチンはレニ ン・アンジオテンシン系を標的として長年研究されて きた. 超高齢社会に突入する我が国において，社会保 障費, 中でも医療費の増加が社会問題とされており, そのためには右肩上がりに増加する医療費を医療の質 を保ちながらも抑制していく方策が求められている. 生活習慣病は多くの国民が罹患している疾患であり， その予防あるいは早期治療介入により生涯治療の薬剤 を少しでも減らすことができれば，医療費削減に大き
く寄与できる可能性がある。 そこで, 高血圧, 糖尿病 に対する治療ワクチンの開発研究の一端を紹介する.

\section{2. 生活習慣病を標的とした能動免疫主導ワクチン}

ワクチンとは自然免疫および獲得免疫の活性化を行 い, 外来の病原体（細菌・ウイルス）あるいはがん細 胞などを標的とし, 樹状細胞, $\mathrm{T}$ 細胞, $\mathrm{B}$ 細胞などの 免疫担当細胞を用いて体液性免疫 (B 細胞が形質細胞 へ分化して，抗原に特異的な抗体を産生するもの）と 細胞性免疫（抗原に特異的な感作 $\mathrm{T}$ 細胞が誘導されて 細胞障害性を担うもの）を惹起する手法である。生活 習慣病を標的としたワクチンにおいては，がんワクチ ンや感染症ワクチンと異なり通常生体内に存在する内 因性タンパク質（ホルモンなど）を標的分子とするた め, 主として抗体産生を誘導する必要があり, 能動免 疫主導のシステムを構築する必要がある。また, 通常 我々の生体は内因性の分子に免疫が作動しないような 免疫寛容があり，これを解除する必要もある．免疫寛 容には中枢性寛容（ネガティブセレクション）と末梢 性寛容（アナジー）の 2 つがあるが, 能動免疫主導ワ クチンでは特に末梢性寛容との関連が重要である。通 常 T 細胞は抗原提示細胞の膜表面に提示される $\mathrm{MHC}$ クラス I あるいはクラス II のアミノ酸配列を認識して 抗原からのシグナルを読み达むが，この抗原認識だけ では T 細胞は反応しない（末梢性寛容：アナジー）. しかし，アジュバントを同時投与することで自然免疫 系が活性化されると，抗原提示細胞の B7（CD80 およ びCD86）の発現増加を介した補助刺激により, 抗原 提示配列による T細胞の活性化が可能となる.この活 性化されたヘルパー T細胞が B 細胞（plasmablast）を 活性化することにより, 標的配列に対する抗体産生が 促されることとなる。この特性を踏まえて上での生活 習慣病ワクチン設計上での違いを図 1 にまとめた。

上記のように，生活習慣病を標的とした治療ワクチ

キーワード: 抗体, 高血圧, 糖尿病, ワクチン

大阪大学大学院 医学系研究科 健康発達医学寄附講座（ $\mathbf{7} 565-0871$ 大阪府吹田市山田丘 2-2)

E-mail: nakagami@gts.med.osaka-u.ac.jp＼cjkstart原稿受領日：2019 年 6 月 23 日，依頼原稿 
従来のワクチン

標的知患

がん、感染店

主な目的

T細胞活性化 (CTL活性)

B細胞による抗体産生

抗原設計

標的分子のMHCクラスを含む

( ( 細胞活性化配列を含む)

キャリア(タンパク質担体)

不要

アジュバント(自然免疫活性化作用)

Th1誘導型

(核酸タイス)

図 1 従来のワクチンと能動免疫ワクチンとの比較

ンは抗体産生誘導を主体とした内在性タンパク質に対 する能動免疫治療である。もし，同時に標的分子に対 する細胞障害性 $\mathrm{T}$ 細胞が活性化されると, 自己免疫疾 患を誘発する可能性があるため, 安全性の担保として 抗原配列設定は極めて重要な要素であり，抗原そのも のが T 細胞を活性化しないように抗原配列から $\mathrm{MHC}$ クラス I およびII 配列を排除することが望ましい．し かし， B 細胞からの安定した抗体産生には $\mathrm{T}$ 細胞の活 性化が必要となるため, 抗原配列の代わりに T 細胞活 性化配列を有する担体タンパク質（キャリア）を用い て抗体産生配列と T細胞活性化配列を融合されるシス テムを用いている。 一般にこのような治療ワクチンで 用いるキャリアとしては，KLH（キーホールリンペッ トヘモシアニン) やVLLP（ウイルスライクパーティク ル）が古くから基礎研究で検討されてきたが(1), 近年 GMP グレードの製剤による臨床試験での投与も行わ れている (後述). また, 末梢性免疫寛容のためにはア ジュバント投与による自然免疫の活性化が必須である が，このアジュバントの種類により産生される IgG サ ブタイプが調整可能であることが知られている。がん ワクチンでは Th1 活性が有意となる核酸夕イプのア ジュバントが好まれており, ADCC（抗体依存性細胞 傷害)や CDC (補体依存性細胞傷害) などの細胞障害 性を高めるエフェクター機能を有する IgG1（マウス では IgG2）の産生が求められるが, 我々のような生活 習慣病ワクチンにおいてはそのようなエフェクター機 能を有しない IgG2 あるいは 4（マウスでは IgG1）の 産生が望まれるため, Th2 活性を高めるタイプのア ジュバントであるアラムなどを用いることが望ましい. すなわち, 生活習慣病ワクチンの開発においては, 最 適な抗原配列設計に加えてキャリアとアジュバントの
選定が重要な要素であり, 実用化に向けてはこの基盤 技術の開発が重要と考えられる。

\section{3. 認知症・高血圧ワクチンの開発の歴史}

生活習慣病・慢性疾患を標的としたワクチンで開発 が進んでいるのは認知症と高血圧である。アルッハイ マー型を標的としたワクチンでは，アミロイドベータ やタウを標的としたワクチンはすでに複数の臨床研究 が開始されている．アミロイドベータのワクチン療法 は 1999 年にヒトAPP（アミロイドベータ前駆タンパ ク質）高発現マウスにアミロイドベー夕（1-42）をア ジュバントとともに免疫治療したのが最初の報告であ る(2). 結果, ワクチン投与により抗アミロイドベー 夕抗体が産生され，若齢マウスでは脳内アミロイドプ ラーク形成，神経突起退縮やアストログリア増殖など の病態進展が抑制され，加齢マウスでは脳内アミロイ ドプラーク形成などの病理変化の進行が抑えられ，さ らに脳内アミロイドプラークの減少も認められた。そ の後, 同様のアミロイド $\beta$ ワクチン療法により, APP 高発現マウスにおいて病理学的所見のみならず加齢に よる学習記憶能力低下の抑制効果も認められることも 報告された $(3,4)$ ．これらの結果を元にして，アミロ イドベータとアジュバント（QS-21）から構成された ワクチン（AN1792）を用いた臨床試験が施行された (5)。この臨床試験において，ワクチンを投与した患 者の 6\%（300 例中 18 例）に髄膜脳炎が発生したこと から安全性に対する課題が懸念された。この課題に対 し, アミロイドベータの抗原配列の中で T細胞活性化 により細胞性免疫を誘導する可能性のある配列を避け, B 細胞を活性化する短い抗原配列を選択する改良がな されている。

高血圧のワクチン開発はレニン・アンジオテンシン 系を標的として活発に研究されてきた. 1980 年代に 最初に試みられたのはレニンを標的するワクチンであ る.この時代では, イヌのレニンあるいはヒトレニン タンパク質を精製してアジュバントとともにラットあ るいはマウスへ投与する実験が行われ，血圧は有意に 低下（30 mmHg 程度）したものの, 腎でのレニン産生 細胞に炎症所見が認められ，安全性の問題が浮き彫り となった $(6,7) .1990$ 年代になりアンジオテンシン I あるいは II に対するワクチンの開発が進められるよう になった。 アンジオテンシン I に対するペプチドワク チンは，キャリアとして破傷風菌トキソイドの部分配 列を用いて抗原と融合されることにより免疫反応を強 化したものが用いられ，さらにアジュバントとしてア ラムを同時投与したものを使用した（PMD-2850）。自 然高血圧発症ラットにこのワクチンを 3 回投与したと 


\section{高血圧ワクチンの臨床試験}

\begin{tabular}{|c|c|c|c|}
\hline 年 & 製剂 & フェーズ/人数 & 結果 \\
\hline 2003 & $\begin{array}{l}\text { 抗原: アンジオテンシン| } \\
\text { キャリア: KLH (PMD3117) } \\
\text { TT(PMD2850) } \\
\text { アジュバント: アラム }\end{array}$ & $\begin{array}{l}\text { フェ一ズ } 1 \\
\text { 健常人男性50人 }\end{array}$ & $\begin{array}{l}\text { アンジオテンシンIに対する抗体価上昇。 } \\
\text { 血圧に変化なし。安全性に問題はなし。 }\end{array}$ \\
\hline 2004 & $\begin{array}{l}\text { 抗原: アンジオテンシンI } \\
\text { キャリア: KLH (PMD3117) } \\
\text { TT(PMD2850) } \\
\text { アジュバント:アラム }\end{array}$ & $\begin{array}{l}\text { フェーズ2 } \\
\text { 高血圧患者27人 }\end{array}$ & $\begin{array}{l}\text { アンジオテンシンIに対する抗体価上昇。 } \\
\text { 血圧に変化なし。安全性に問題はなし。 }\end{array}$ \\
\hline 2007 & $\begin{array}{l}\text { 抗原:アンジオテンシンII } \\
\text { キャリア:VLP (AngQb) } \\
\text { アジュバント:アラム }\end{array}$ & $\begin{array}{l}\text { フェーズ1 } \\
\text { 健常人男性16人 } \\
\text { (実薬12人、偽薬4人) }\end{array}$ & $\begin{array}{l}\text { アンジオテンシンIIに対する抗体価上昇。 } \\
\text { 血圧に変化なし。安全性に問題はな。 }\end{array}$ \\
\hline 2008 & $\begin{array}{l}\text { 抗原: アンジオテンシンII } \\
\text { キャリア:VLP (AngQb) } \\
\text { アジュバント:アラム }\end{array}$ & $\begin{array}{l}\text { フェーズ2 } \\
\text { 高血圧患者 } 72 \text { 人 } \\
\text { (高用量24人、低用量 } 24 \\
\text { 人、偽薬24人) }\end{array}$ & $\begin{array}{l}\text { アンジオテンシンIII対する抗体価上昇。 } \\
\text { 高用量群で血圧が有意に低下。安全性 } \\
\text { に問題はなし。 }\end{array}$ \\
\hline 2010 & $\begin{array}{l}\text { 抗原:アンジオテンシン॥ } \\
\text { 新規アジュバント使用, } \\
\text { CoVaccine } \mathrm{HT}^{\mathrm{TM}}\end{array}$ & フェーズ $2 b$ & $\begin{array}{l}\text { 有害事象のため途中で試験中止(詳細 } \\
\text { 不明) }\end{array}$ \\
\hline 201 & $\begin{array}{l}\text { 抗原: アンジオテンシン॥ } \\
\text { DNAワクチン(AMG0201) }\end{array}$ & $\begin{array}{l}\text { フェーズ } 1 \\
\text { 高血圧患者 } 24 \text { 人 } \\
\text { (高用量9人、低用量9人、 } \\
\text { 偽薬6人) }\end{array}$ & 実施中。 \\
\hline
\end{tabular}

図 2 高血圧ワクチンの臨床開発の歴史

ころ，抗体価の有意な上昇と血圧の有意な低下を認め た (8)。そこで, ほぼ同様のコンセプトで KLHをキャ リアとして用いたワクチン（PMD-3117）を用いてヒ 卜臨床試験を行ったが, 抗体価の上昇は認められたも のの有意な降圧は認められなかった(9)。一方，アン ジオテンシン II に対するペプチドワクチンとしてキャ リアであるVLP とアンジオテンシン II を融合したワ クチン（CYT006-AngQb）も, 同様に自然高血圧発症 ラットを用いた動物実験で有意な抗体価の上昇と血圧 の有意な低下を認めている (10)。この CYT006-AngQb を用いたヒト臨床試験では，このワクチンを高血圧患 者に低濃度 $(100 \mu \mathrm{g})$ と高濃度 $(300 \mu \mathrm{g})$ の 2 種類の 濃度で $0,4,12$ 週の 3 回の投与を行い, 投与後 14 週 後 (3 回目ワクチン接種後 2 週後) の 24 時間血圧の平 均值で評価したところ, 高濃度群と無治療群との間で 収縮期血圧 $9 \mathrm{mmHg}$, 拡張期血圧 $4 \mathrm{mmHg}$ の血圧低下 を認めた．有害事象も軽度の注射部位での反応のみで, 重大な事例は認められなかった(11)。これは少数の軽 〜中等症高血圧症患者を対象にした短期間での限られ た成績ではあるが高血圧ワクチンの治療効果を初めて ヒトで確認した画期的な報告であった。しかし，その 後行われた第 II 相試験（高血圧患者 69 人を対象とし た二重盲検プラセボ対照試験）では, CYT006-AngQb による有意な血圧の低下を示すことができなかった． 我々も後述する独自のアンジオテンシン II を標的とし たワクチンの研究結果を基盤として, 2018 年 4 月から
阪大発のベンチャーであるアンジェス主導の企業治験 （フェーズ I ）をオーストラリアで開始している（図 2).

\section{4. 生活習慣病に対する治療ワクチンの基礎研究}

我々も同様にアンジオテンシン II を標的としたワク チンを設計し，キャリアとしては KLH を用いアンジ オテンシン II とのコンジュゲートワクチンを作成した. このワクチンシステムでは, T細胞は抗原提示細胞の 膜表面に提示される MHC クラス I あるいはクラス II のアミノ酸配列を認識して抗原からのシグナルを読み 込むが，同時にアジュバントによって補助刺激の B7 （CD80 および CD86）からのシグナルが入ることによ り,ヘルパー $\mathrm{T}$ 細胞が活性化され，最終的に $\mathrm{B}$ 細胞か らの抗体産生能が高まると考えられる（図 3)。このぺ プチドワクチンをマウス抄よびラットに投与したとこ ろ，抗体価の有意な上昇とアンジオテンシン II の投与に よりもたらされる血圧上昇を有意に抑制した。また, アンジオテンシン II 投与により誘導された心重量の増加, 血管周囲の繊維化もワクチン投与群では有意に抑制さ れていた (12)。同様の仕組みで我々は DNA ワクチン の開発も行っており (13)，またラット脳梗塞あるいは 心筋梗塞モデルにおいてもアンジオテンシン II ワクチ ン投与により臟器保護効果が確認できている $(14,15)$.

糖尿病を標的としたワクチンとしては，1 型糖尿病 治療を目指した免疫寛容ワクチンが臨床研究まで検討 されている。1 型糖尿病では膵ベー夕細胞の傷害に伴 


\section{アンジオテンシン【ペプチドワクチンの仕組み}

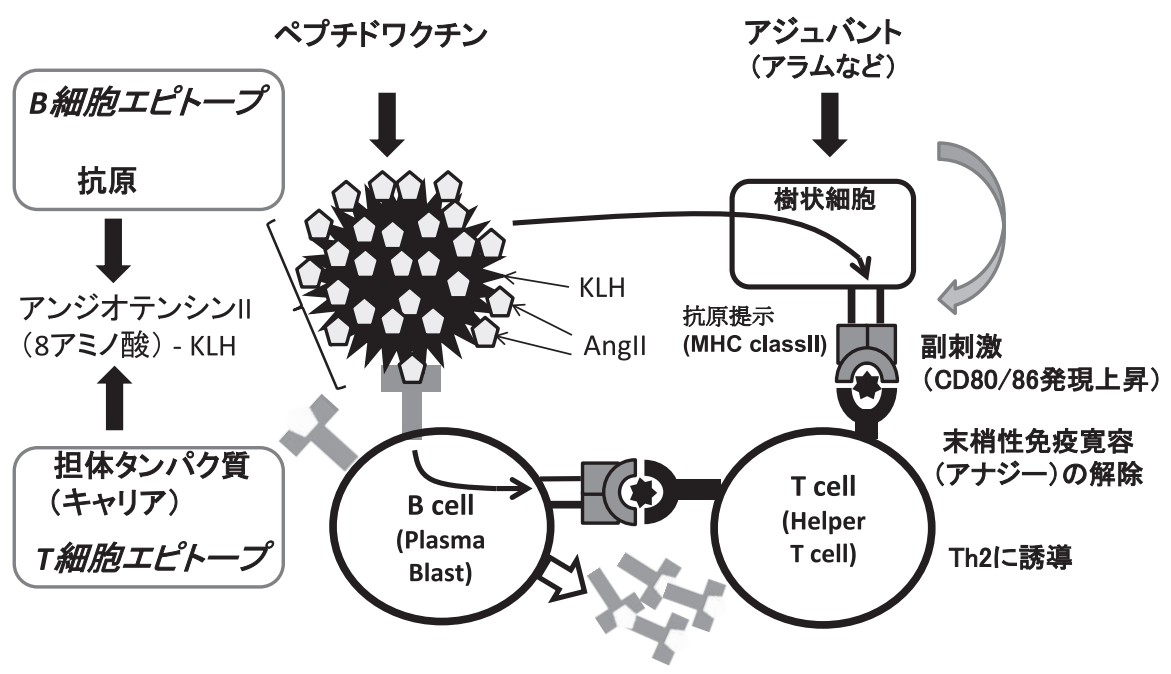

抗アンジオテンシンII抗体産生誘導

図 3 アンジオテンシン Iを標的としたペプチドワクチンの仕組み

抗原・キャリア·アジュバントを組み合わせることにより, 標的分子に特異的な抗体産生を誘導するワクチン

いGAD65 抗体が上昇することが知られており，ヒト 臨床においても診断マーカーとして用いられている. この GAD65 を標的とした免疫寛容ワクチンは動物実 験では効果が認められ, 初期のヒト臨床試験において も効果が認められた症例があったが, その後の大規模 試験においてはインスリン分泌量に有意な変化を与え ることができなかった(16)。その原因として, GAD65 抗体が出現する頃にはすでに膵べー夕細胞の障害によ るインスリン分泌能の低下が始まってしまっている ことが挙げられる。 そこでより早期の診断が可能な 標的分子として, 我々は glial fibrillary acidic protein （GFAP）に着目した検討を行い，抗 GFAP 抗体が 1 型 糖尿病モデルマウスおよびヒト糖尿病患者で上昇して いることを確認している(17)。また，2型糖尿病を 標的としたワクチンとして, dipeptidyl peptidase-4 （DPP4）を標的とした治療ワクチンを開発し，マウス で DPP4 阻害薬と同様にインクレチンホルモン GLP-1 の分解を阻害してインスリン分泌を高めて血糖降下作 用を有することを明らかとしている(18).

脂質異常症に関するワクチンとして, HDLを上昇さ せる目的で cholesteryl ester transfer protein (CETP) を標的としたプラスミド DNA ワクチンの動物実験で の検討が報告されている(19). ウサギを用いた検討で CETP に対する DNA ワクチンによる HDL の上昇と動 脈硬化の抑制が報告されているが，これまで報告され ている CETP 阻害薬のヒト臨床試験で有効性を得られ なかったこともありその後あまりワクチン開発も進ん
でいない，近年, LDL受容体の分解抑制による発現上 昇効果を有する PCSK9 抗体が臨床で使用されている が，同様にPCSK9 を標的としたワクチン開発も進め られており, 今後の開発が期待されている $(20,21)$.

動脈硬化の予防あるいは治療に対しても複数の報告 がされている，その標的分子は，これまで動脈硬化と の関連が報告されている apolipoprotein B-100（ApoB100) や heat shock protein（HSP）60/65 であるが, 酸 化 LDLを特異的に認識する抗体を誘導するワクチン も動物実験での有効性が示されており, 脂質や局所炎 症のコントロールをワクチンで持続的かつ安定してで きれば，今後の治療法として大いに期待できる $(22)$. また，これらのワクチンを複数同時に用いるような試 みも動物実験では試されており，ますます発展が期待 できる研究領域となっている.

\section{5. おわりに}

このような生活習慣病に対するワクチン治療の臨床 的メリットとしては, 薬物アドヒアランスの改善が挙 げられる。特に高齢者における薬の多剂併用（ポリ ファーマシー）の増加により, 飲み忘れや服薬管理の 必要性が高い患者が増加している。薬物療法において 腎機能や肝機能の低下など薬物動態の変化, 合併症に よるポリファーマシーの増加とそれに伴う副作用の増 強など多くの問題が顕在化しており, 薬剤を隇らすこ とによって得られる社会的なメリットは大きい.

さらに将来的には予防医学の実現に向けたワクチン 
の応用を期待している．高血圧に対する予防治療の可 能性の例として, 自然高血圧発症ラットを用いた検討 で, 高血圧発症前の若いラットにアンジオテンシン 変換酵素阻害薬 (ACEI) あるいはアンジオテンシン受 容体拮抗薬（ARB）を投与しておくと, 投薬中止後も 長期にわたって高血圧発症が抑制されたという興味 深い報告がある。これは, 降圧薬であるレニン・アン ジオテンシン系の遮断薬が血圧上昇前に個体で起こっ ている何らかの反応を抑制することによって，高血圧 発症を遅らせることができることを示唆している.こ の基礎研究に基付いて行われた臨床研究が TROPHY 試験であり，これは高血圧前症を初めて対象とした 臨床介入試験である. TROPHY 試験は, 正常高值血 圧者（収縮期血圧／拡張期血圧がミ139/85 89 又は $130 \sim 139 / \leqq 89 \mathrm{mmHg}$ の人）を対象に, ARB（ブロプ レス 1 日 1 回 $16 \mathrm{mg}$ ）投与群とプラセボ投与群に分け て，それぞれ 2 年間投与 (無作為割付け二重盲検) し た後, その後 2 年間, 両群ともプラセボを投与するこ とによる高血圧症の発症率を比較した試験である。結 果, 試験開始後 2 年を経た時点の $\mathrm{ARB}$ 投与群の高血圧 発症率は $13.6 \%$ ，プラセボ投与群は $40.4 \%$ 。また，両 群ともプラセボ投与に切り替えた 2 年間を含む試験開 始 4 年後のブロプレス投与群における発症率は $53.2 \%$, プラセボ群が $63.0 \%$ 。試験終了時の 4 年目では, ブロ プレス投与群がプラセボ投与群と比較して, 高血圧症 の発症リスクを $15.6 \%$ 減少させるという結果が得られ ている (23)。この TROPHY 試験における 4 年間の高
血圧症発症リスク軽減率は多大とはいえないが，早期 の介入が疾患予防の観点で大きな意味を持つ可能性が あり，より早期に治療を開始することで高血圧症の発 症・進展を遅らせる可能性がある.

高血圧ワクチン治療の実現は降圧治療法のオプショ ンを増やし治療法の選択肢を増やすことに加えて, 薬 剤アドヒアランスの改善や医療費抑制も期待できる. これらの次世代高血圧治療の今後に期待したい.

著者の利益相反 : 中神啓徳 (アンジェス株式会社, アンチエ イジングペプタイド株式会社, 株式会社ダイセル, 帝人株式 会社, 株式会社ファンペップ).

\section{文献}

1) Plescia OJ. Curr Top Microbiol Immunol. 1969;50:78-106.

2) Schenk D, et al. Nature. 1999;400:173-177.

3) Morgan D, et al. Nature. 2000;408:982-985.

4) Janus $C$, et al. Nature. 2000;408:979-982.

5) Gilman S, et al. Neurology. 2005;64:1553-1562.

6) Michel JB, et al. Proc Natl Acad Sci U S A. 1987;84:4346-4350.

7) Michel JB, et al. Circulation. 1990;81:1899-1910.

8) Gardiner SM, et al. Br J Pharmacol. 2000;129:1178-1182.

9) Brown MJ, et al. Clin Sci (Lond). 2004;107:167-173.

10) Ambuhl PM, et al. J Hypertens. 2007;25:63-72.

11) Tissot AC, et al. Lancet. 2008;371:821-827.

12) Nakagami F, et al. PLoS One. 2013;8:e60493.

13) Koriyama H, et al. Hypertension. 2015;66:167-174.

14) Wakayama K, et al. Stroke. 2017;48:1362-1368.

15) Watanabe R, et al. Sci Rep. 2017;7:43920.

16) Ludvigsson J, et al. N Engl J Med. 2008;359:1909-1920.

17) Pang Z, et al. FEBS Lett. 2017;591:129-136.

18) Pang Z, et al. Proc Natl Acad Sci U S A. 2014;111: E1256-E1263.

19) Landlinger C, et al. Eur Heart J. 2017;38:2499-2507.

20) Kimura T, et al. Autoimmunity. 2015;48:152-160.

21) Julius S, et al. N Engl J Med. 2006;354:1685-1697.

\title{
Development of therapeutic vaccine for life style-related diseases
}

\author{
Hironori Nakagami
}

Department of Health Development and Medicine, Osaka University Graduate School of Medicine

\begin{abstract}
In the $18^{\text {th }}$ century, Edward Jenner proposed the vaccine for smallpox as a first vaccine therapy based on the legend that a vaccinia prevents the infection with smallpox. Recently, the therapeutic target of vaccine will expand from infectious diseases to various diseases, such as amyloid $\beta$ or tau vaccine for Alzheimer's disease. We are now going to develop a therapeutic vaccine to lifestyle-related diseases (i.e. high blood pressure), and aim to realize a novel therapy which will be injected once or twice per year from a daily medication. For this purpose, the appropriate choice of an antigen, carrier and adjuvants should be required to activate hormonal immunity by the vaccine, leading to efficient antibody production without toxicity, because the therapeutic target of our vaccine is an endogenous protein (i.e. hormone). The clinical advantage of this therapeutic vaccine is to improve the medical adherence and drug management because the multiple drug users are increased in particular old patients, so called polypharmacy. If the vaccine will take place of a part of medicine in future, it may give us a novel therapeutic option with several social benefits.
\end{abstract}

